\title{
Hubungan Kadar Asam Urat, Laktat Dehidrogenase, Aspartat Aminotransferase Serum Penderita Preeklamsi Berat Disertai Komplikasi dan Tanpa Komplikasi
}

\author{
Galih Apriyadi, ${ }^{1}$ Budi Handono, ${ }^{2}$ Akhmad Yogi Pramatirta, ${ }^{2}$ Jusuf S. Effendi, ${ }^{2}$ \\ Tita Husniwati Madjid, ${ }^{2}$ Adhi Pribadi ${ }^{2}$ \\ ${ }^{1}$ RSI PKU Muhammadiyah Kabupaten Tegal \\ ${ }^{2}$ Departemen Obstetri \& Ginekologi, Fakultas Kedokteran Universitas Padjadjaran / \\ Rumah Sakit Dr. Hasan Sadikin Bandung \\ Korespondensi: Galih Apriyadi, Email : galihapriyadi@gmail.com
}

\begin{abstract}
Abstrak
Tujuan: penelitian ini untuk mencari perbedaan kadar asam urat, laktat dehydrogenase (LDH) dan aspartat aminotransferase (AST) pada serum penderita preeklamsi berat disertai komplikasi dan tanpa komplikasi dan mengukur kuatnya hubungan peningkatan kadar asam urat, LDH dan AST dengan peningkatan risiko terjadinya komplikasi pada pasien preeklamsi berat.

Metode: Rancangan penelitian ini adalah penelitian comparative cross sectional dengan metode consecutive sampling. Subjek penelitian adalah penderita preeklamsi berat disertai komplikasi dan tanpa komplikasi $(\mathrm{n}=68)$.

Hasil: Hasil penelitian didapatkan perbedaan kadar asam urat, LDH dan AST pada kedua kelompok secara bermakna dengan nilai $\mathrm{p} \leq 0,05$. Peningkatan kadar asam urat, LDH dan AST berhubungan dengan peningkatan risiko terjadinya komplikasi dengan nilai cut off kadar asam urat $>6,5 \mathrm{mg} / \mathrm{dL}$ sebesar $33 \mathrm{kali}, \mathrm{LDH}>573 \mathrm{U} / \mathrm{L}$ sebesar 8,95 kali dan AST > 30 U/L sebesar 5,19 kali. Jika terjadi peningkatan seluruh kadar asam urat, LDH dan AST diatas nilai cut off maka risiko terjadinya komplikasi sebesar $98,1 \%$.

Kesimpulan: Penelitian ini menyimpulkan kadar asam urat, LDH, AST pada preeklamsi berat disertai komplikasi lebih tinggi dibandingkan preeklamsi berat tanpa komplikasi dan peningkatan kadar asam urat, LDH, AST berhubungan dengan peningkatan risiko terjadinya komplikasi pada preeklamsi berat.
\end{abstract}

Kata kunci: Preeklamsi berat, komplikasi, asam urat, LDH, AST

\section{Relations of Uric Acid, Lactat Dehydrogenase, and Aspartat Aminotransferase Serum LevelIn Severe Preeclampsia with and Without Complications}

\begin{abstract}
Objective: This study compared level of uric acid, LDH, and AST level between severe preeclampsia patients with complication and without complication, and measured correlation between the rise level of uric acid, LDH and AST towards the increased risk of complication in patient with severe preeclampsia.

Methods: The study design was comparative cross sectional study with consecutive sampling method that compare the results of laboratorium uric acid, LDH, AST between complications and without complications group. Subjects of this study were severe preeclampsia patients with and without complication that fulfilled study criteria $(n=68)$. Result: It is revealed that the differences level of uric acid, LDH, and AST in both groups were significant with $p$ value $\leq 0.05$. Increase level of uric acid, $L D H$, and AST were related to inreased risk of complication in severe preeclampsia occurence with cut off point of uric acid level of $>6.5 \mathrm{mg} / \mathrm{dL}$ by 33 times, LDH level of $>573 \mathrm{U} / \mathrm{L}$ by 8.95 times, and AST level of $>30 \mathrm{U} / \mathrm{L}$ by 5.19 times. If all uric acid, LDH, and AST level rise above the cut off value so the risk of complication of severe preeclampsia will rise by $98.1 \%$.

Conclusion: It is concluded that level of uric acid, LDH, and AST in severe preeclampsia with complication were higher than severe preeclampsia without complication and the rise of uric acid, LDH, and AST were related with the rise of complication risk on severe preeclampsia.
\end{abstract}

Keyword: Severe preeclampsia, complication, uric acid, LDH, AST 


\section{Latar Belakang}

World Health Organization memperkirakan 287.000 kematian ibu terjadi pada tahun 2010 dengan berbagai faktor risiko. Salah satu faktor risikonya adalah hipertensi dalam kehamilan. Gangguan hipertensi dalam kehamilan terjadi pada hampir $18 \%$ dari seluruh kematian ibu di seluruh dunia. ${ }^{1,2}$

Penyakit hipertensi, bersama perdarahan dan infeksi membentuk trias yang mematikan yang berperan besar dalam angka morbiditas dan mortalitas ibu. Sindrom preeklamsi, salah satu jenis dari hipertensi dalam kehamilan merupakan kelainan yang paling berbahaya. Pada tahun 2014 - 2015 jumlah kematian ibu di Rumah Sakit Dr. Hasan Sadikin Bandung sebanyak 45 kasus dan preeklamsi berat menjadi penyebab kematian sebanyak 25 kasus. ${ }^{1,3}$

Preeklamsi berat menyebabkan beberapa komplikasi yang dapat meningkatkan morbiditas dan mortalitas ibu maupun janin. Komplikasi preeklamsi dapat terjadi pada kardiovaskular, hati, otak dan ginjal. ${ }^{2,4}$ Ketika terjadi komplikasi pada suatu organ, maka akan terjadi kerusakan organ. Pada kerusakan organ tersebut maka akan terjadi peningkatan kadar marker laboratorium. Pada penelitian sebelumnya didapatkan bahwa serum asam urat, laktat dehidrogenase (LDH) dan aspartat aminotransferase (AST) merupakan salah satu marker yang signifikan dalam memprediksi komplikasi pada preeklamsi berat. $^{5}$

Tujuan penelitian ini mencari perbedaan kadar asam urat, LDH, AST pada serum penderita preeklamsi berat disertai komplikasi dan tanpa komplikasi, serta mengukur kuatnya hubungan peningkatan kadar asam urat, $\mathrm{LDH}, \mathrm{AST}$, dengan peningkatan risiko terjadinya komplikasi pada pasien preeklamsi berat.

\section{Metode dan Subjek Penelitian}

Penelitian ini merupakan penelitian comparative cross sectional yang membandingkan kadar asam urat, LDH, AST pada serum penderita preeklamsi berat disertai komplikasi dan tanpa komplikasi, serta mengukur kuatnya hubungan peningkatan kadar asam urat, LDH, AST, dengan peningkatan risiko terjadinya komplikasi pada pasien preeklamsi berat. Persetujuan etik dikeluarkan oleh Komite Etik Penelitian RSUP Dr. Hasan Sadikin Bandung. Setiap subjek yang menyetujui untuk ikut dalam penelitian akan dijaga kerahasiannya.

Subjek dalam penelitian ini adalah penderita preeklamsi berat disertai komplikasi dan tanpa komplikasi yang berobat ke Rumah Sakit Dr. Hasan Sadikin Bandung dan rumah sakit jejaring (RSUD Dr. Slamet Kabupaten Garut, RSUD Kabupaten Sumedang, RSUD Gunung Jati Kota Cirebon, RSUD Majalaya Kabupaten Bandung dan RSUD Soreang Kabupaten Bandung) pada bulan November - Desember 2016. Kriteria eksklusi adalah pasien yang telah menderita kelainan pada sistem kardiovaskuler, hati, otak dan ginjal sebelum menderita preeklamsi berat dan mengundurkan diri dari penelitian. Pasien yang mengalami komplikasi tersebut akan dimasukkan ke kelompok preeklamsi berat disertai komplikasi. Jumlah sampel minimal adalah 34 pada setiap kelompok penelitian.

Pasien yang telah setuju ikut dalam penelitian akan dilakukan anamnesis kemudian akan dilakukan pemeriksaan darah yang diambil dari pembuluh darah vena. Sampel diperiksa dengan prinsip spektrofotometri dan metode enzimatik kalorimetri.

Data yang telah dikumpulkan akan dianalisis dengan SPSS versi 21 for Windows. Data kemudian akan dianalisis dengan uji Mann Whitney untuk menguji perbedaan antara kedua kelompok. Setelah didapatkan perbedaan maka akan dicari cut of points 
dengan menggunakan kurva Receiver Operating Characteristics. Untuk mengukur hubungan antara semua variable penelitian akan digunakan regresi logistik berganda. Untuk menguji normalitas variable numerik digunakan Kolmogorov-Smirnov test.

\section{Hasil}

Penelitian tentang perbedaan kadar asam urat, LDH, AST serum penderita preeklamsi berat disertai komplikasi dan tanpa komplikasi telah dilakukan terhadap 40 pasien yang datang berobat ke Rumah Sakit Dr. Hasan Sadikin Bandung dan 28 pasien yang datang berobat ke rumah sakit jejaring. Penelitian dari 34 pasien dengan komplikasi menunjukkan 14 pasien menderita komplikasi hati, 7 pasien menderita komplikasi otak dan hati, 4 pasien menderita komplikasi otak, 3 pasien menderita komplikasi ginjal, 3 pasien menderita komplikasi hati dan ginjal, 1 pasien menderita komplikasi jantung, 1 pasien menderita komplikasi jantung dan hati serta 1 pasien menderita komplikasi jantung dan otak. Karakteriktik subjek penelitian dapat dilihat dalam Tabel 1.
Dari tabel 1 tampak karakteristik subjek penelitian yang meliputi usia dan paritas pada kedua kelompok penelitian tidak menunjukkan ada perbedaan yang bermakna ( $>>0,05$ ). Usia didominasi umur 20-34 tahun sedangkan paritas didominasi multiparitas.

Hasil uji statistik menunjukkan perbedaan bermakna pada nilai asam urat kelompok preeklamsi berat disertai komplikasi nilai mediannya $8,4 \mathrm{mg} / \mathrm{dL}$ dan rentangnya $6,3-14,3 \mathrm{mg} / \mathrm{dL}$. Nilai asam urat pada kelompok preeklamsi berat tanpa komplikasi nilai mediannya $5 \mathrm{mg} / \mathrm{dL}$ dan rentangnya $2,7-6,9 \mathrm{mg} / \mathrm{dL}$. Nilai $\mathrm{LDH}$ pada kelompok preeklamsi berat disertai komplikasi nilai mediannya $848 \mathrm{U} / \mathrm{L}$ dan rentangnya 452 - 4211 U/L. Nilai LDH pada kelompok preeklamsi berat tanpa komplikasi nilai mediannya $424 \mathrm{U} / \mathrm{L}$ dan rentangnya 251 - 596 U/L. Nilai AST pada kelompok preeklamsi berat disertai komplikasi nilai mediannya $42 \mathrm{U} / \mathrm{L}$ dan rentangnya 18-633 U/L. Nilai AST pada kelompok preeklamsi berat tanpa komplikasi nilai mediannya 16,5 $\mathrm{U} / \mathrm{L}$ dan rentangnya $7-33 \mathrm{U} / \mathrm{L}$.

Dari hasil perhitungan melalui kurva ROC diperoleh cut off point yang dapat

Tabel 1 Karakteristik Subjek Penelitian

\begin{tabular}{cccc}
\hline & \multicolumn{2}{c}{ Kelompok Preeklamsi } & \\
Karakteristik & $\begin{array}{c}\text { Dersertai } \\
\text { komplikasi } \\
\text { (n=34) }\end{array}$ & $\begin{array}{c}\text { Tanpa } \\
\text { komplikasi } \\
(\mathbf{n = 3 4 )}\end{array}$ & \\
\cline { 2 - 3 } & \multicolumn{3}{c}{ Nilai p } \\
Usia (tahun) : & 5 & 2 & $>0,05$ \\
$<20$ & 17 & 21 & \\
$20-34$ & 12 & 11 & \\
$\geq 35$ & $30,3(7,3)$ & $30,7(6,3)$ & \\
Rerata (SD) & $16-42$ & $18-41$ & \\
Rentang & & & \\
Paritas : & 12 & 15 & \\
Primipara & 22 & 19 & \\
Multipara & & & \\
\hline
\end{tabular}


Tabel 2 Perbandingan Kadar Asam Urat, LDH dan AST pada Kedua Kelompok Penelitian

\begin{tabular}{|c|c|c|c|}
\hline \multirow[b]{2}{*}{ Variabel } & \multicolumn{2}{|c|}{$\begin{array}{c}\text { Kelompok Preeklamsi } \\
\text { Berat }\end{array}$} & \multirow[b]{2}{*}{ Nilai p } \\
\hline & $\begin{array}{c}\text { Disertai } \\
\text { komplikasi } \\
(n=34)\end{array}$ & $\begin{array}{c}\text { Tanpa } \\
\text { komplikasi } \\
(n=34)\end{array}$ & \\
\hline Asam urat (mg/dl) : & & & $\leq 0,05$ \\
\hline Median & 8,4 & 5 & \\
\hline Rentang & $6,3-14,3$ & $2,7-6,9$ & \\
\hline Kadar LDH (mg/dl) : & & & $\leq 0,05$ \\
\hline Median & 848 & 424 & \\
\hline Rentang & $452-4211$ & $251-596$ & \\
\hline Kadar AST (mg/dl) : & & & $\leq 0,05$ \\
\hline Median & 42 & 16,5 & \\
\hline Rentang & $18-633$ & $7-33$ & \\
\hline
\end{tabular}

Tabel 3 Nilai Cut Off dari Kadar Asam Urat, LDH dan AST yang dapat Dipakai Sebagai Prediktor Kejadian Komplikasi pada Preeklamsi Berat

\begin{tabular}{lcccc}
\hline \multicolumn{1}{c}{ Variabel } & Nilai cut off $^{*}$ & $\begin{array}{c}\text { Sensitifitas } \\
(\mathbf{\%})\end{array}$ & $\begin{array}{c}\text { Spesifisitas } \\
(\%)\end{array}$ & $\begin{array}{c}\text { Akurasi } \\
(\%)\end{array}$ \\
\hline Kadar Asam urat & $>6,5$ & 97,1 & 97,1 & 97,1 \\
Kadar LDH & $>573$ & 88,2 & 97,1 & 92,6 \\
Kadar AST & $>30$ & 79,4 & 94,1 & 86,8 \\
\hline
\end{tabular}

Tabel 4 Hubungan Kadar Asam Urat, LDH dan AST dengan Kejadian Komplikasi pada Preeklamsi Berat

\begin{tabular}{|c|c|c|c|c|}
\hline $\begin{array}{c}\text { Variabel } \\
\text { (nilai cut off) }\end{array}$ & $\begin{array}{c}\text { Disertai komplikasi } \\
(n=34)\end{array}$ & $\begin{array}{c}\text { Tanpa komplikasi } \\
(n=34)\end{array}$ & & RP (IK 95\%) \\
\hline Kadar asam urat & & & $\leq 0,05$ & \\
\hline$>6,5$ & 33 & 1 & & 33,0 \\
\hline$\leq 6,5$ & 1 & 33 & & \\
\hline Kadar LDH & & & $\leq 0,05$ & \\
\hline$>573$ & 30 & 1 & & 8,95 \\
\hline$\leq 573$ & 4 & 33 & & \\
\hline Kadar AST & & & $\leq 0,05$ & \\
\hline$>30$ & 27 & 2 & & 5,19 \\
\hline$\leq 30$ & 7 & 32 & & \\
\hline
\end{tabular}

dipakai sebagai prediktor komplikasi pada preeklamsi berat untuk asam urat adalah $>$ $6,5 \mathrm{mg} / \mathrm{dL}$, untuk kadar LDH $>573 \mathrm{U} / \mathrm{L}$ dan untuk kadar AST $>30 \mathrm{U} / \mathrm{L}$. Kadar asam urat
$>6,5 \mathrm{mg} / \mathrm{dL}$ memiliki sensitifitas, spesifitas dan akurasi yang paling tinggi yaitu $97,1 \%$. (Tabel 3) 
Tabel 5 Korelasi antara Umur dengan Kadar Asam Urat, LDH dan AST

\begin{tabular}{|c|c|c|c|}
\hline \multirow[b]{2}{*}{ Variabel } & \multicolumn{2}{|c|}{ Umur } & \multirow[t]{2}{*}{ Nilai $p$} \\
\hline & $\geq 35$ tahun & $<35$ tahun & \\
\hline \multicolumn{4}{|c|}{ Preeklamsi berat disertai } \\
\hline \multicolumn{4}{|l|}{ komplikai } \\
\hline Asam urat & & & $>0,05$ \\
\hline Median & 8,75 & 8 & \\
\hline Rentang & $7-12,3$ & $6,3-14,3$ & \\
\hline LDH & & & $\leq 0,05$ \\
\hline Median & 979 & 732 & \\
\hline Rentang & $579-4211$ & $452-1815$ & \\
\hline AST & & & $>0,05$ \\
\hline Median & 92,5 & 39 & \\
\hline Rentang & $23-633$ & $18-196$ & \\
\hline \multicolumn{4}{|c|}{ Preeklamsi berat tanpa } \\
\hline komplikai & & & $>0,05$ \\
\hline Asam urat & 4,9 & 5,4 & \\
\hline Median & $3,3-6,5$ & $2,7-6,9$ & \\
\hline \multicolumn{4}{|l|}{ Rentang } \\
\hline LDH & & & $>0,05$ \\
\hline Median & 415 & 433 & \\
\hline Rentang & $254-543$ & $251-596$ & \\
\hline AST & & & $>0,05$ \\
\hline Median & 18 & 16 & \\
\hline Rentang & $11-31$ & $7-33$ & \\
\hline
\end{tabular}

Penderita preeklamsi berat dengan asam urat $>6,5 \mathrm{mg} / \mathrm{dL}$ memiliki risiko untuk terjadinya komplikasi sebesar 33,0 kali bila dibandingkan dengan penderita preeklamsi berat dengan asam urat $\leq 6,5 \mathrm{mg} / \mathrm{dl}$. Penderita preeklamsi berat yang memiliki kadar LDH $>$ $573 \mathrm{U} / \mathrm{L}$ risiko untuk terjadinya komplikasi sebesar 8,95 kali bila dibandingkan dengan yang memiliki kadar $\mathrm{LDH} \leq 573 \mathrm{U} / \mathrm{L}$ dan untuk kadar AST $>30 \mathrm{U} / \mathrm{L}$ risiko penderita preeklamsi berat akan mengalami komplikasi sebesar 5,19 kali bila dibandingkan dengan yang memiliki kadar AST $\leq 30 \mathrm{U} / \mathrm{L}$. Hal ini menunjukkan bahwa nilai asam urat sangat bermakna. (Tabel 4)

Jika kadar asam urat, kadar LDH, dan kadar AST diatas nilai cut off maka risiko terjadinya komplikasi pada penderita preeklamsi berat sebesar 98,1\%.

Penelitian ini didapatkan perbedaan yang signifikan bahwa nilai marker serum dipengaruhi oleh umur yang ditemukan bila kadar LDH dibandingkan dengan umur $<35$ tahun dan $\geq 35$ tahun. (Tabel 5)

\section{Pembahasan}

Secara teori wanita dengan risiko tinggi berkembang preeklamsi berat pada usia $<20$ tahun atau $\geq 35$ tahun, namun pada penelitian ini sebagian besar umur subjek 20-34 tahun yang merupakan $55 \%$ dari jumlah total sampel. Hal ini mungkin disebabkan oleh semakin majunya tingkat pendidikan dan 
usia menikah yang lebih matang pada wanita sehingga wanita tersebut hamil dengan usia yang lebih tua yang menyebabkan prevalensi terjadinya preeklamsi berat telah bergeser kearah usia yang lebih tua. ${ }^{1,2}$

Karakteristik lain subjek yang tidak sesuai dengan teori adalah paritas subjek. Pada teori sebelumnya dikatakan preeklamsi terjadi teritama pada primigravida dibandingkan multigravida. Pada penelitian ini mayoritas subjek merupakan multigravida. Hal ini mungkin disebabkan banyak faktor yaitu seperti pasien baru menikah kembali, kehamilan multifetus, umur yang ekstrim dan lain-lain. ${ }^{1,2}$

Peningkatan kadar asam urat, LDH dan AST berhubungan erat dengan kerusakan jaringan yang terjadi pada preeklamsi. Ketika kerusakan ini semakin berat maka kadar marker serum ini akan semakin meningkat. ${ }^{6-12}$ Penelitian ini menunjukkan perbedaan kadar asam urat, LDH dan AST pada kedua kelompok penelitian. Kadar asam urat, LDH dan AST pada kelompok preeklamsi berat disertai komplikasi lebih tinggi dibandingkan pada kelompok preeklamsi berat tanpa komplikasi. Penelitian ini juga menunjukkan perbedaan kadar asam urat, LDH dan AST pada kedua kelompok bermakna secara statistik. Nilai median kelompok preeklamsi berat disertai komplikasi berada pada nilai tidak normal sedangkan kelompok tanpa komplikasi masih berada dalam batas normal. Nilai asam urat dan LDH juga bermakna secara klinis sedangkan nilai AST tidak bermakna secara klinis. Hal ini menunjukkan bahwa belum tentu nilai yang bermakna secara statistik memberikan kegunaan secara klinis. Hasil penelitian ini sesuai dengan hasil penelitian sebelumnya., 9-13

Penelitian ini menunjukkan nilai cut off asam urat dan LDH berada pada nilai tidak normal sedangkan nilai AST masih berada dalam nilai normal. Nilai cut off AST walaupun berada dalam batas normal namun tetap menunjukkan risiko yang sangat signifikan yaitu 5 kali sehingga batas nilai atas 32 untuk nilai normal AST perlu dilakukan peninjauan ulang.

Penelitian ini didapatkan bahwa bila terjadi peningkatan seluruh kadar asam urat, LDH dan AST diatas nilai cut off maka kemungkinan terjadi komplikasi sebesar $98,1 \%$. Pada penelitian sebelumnya belum ada yang mendapatkan angka sebesar ini karena penelitian masih terpisah-pisah untuk masing-masing marker sedangkan dari penelitian martin dkk tidak dilakukan penghitungan risiko terjadinya komplikasi. ${ }^{6}$, $10-13$

Keterbatasan pada penelitian ini yaitu komplikasi yang diteliti hanya komplikasi pada kardiovaskular, hati, otak dan ginjal sehingga belum menggambarkan seluruh komplikasi pada preeklamsi berat. Pada penelitian ini juga memasukkan seluruh rentang umur sehingga pada kadar LDH nilainya masih dipengaruhi oleh usia. ${ }^{9}, 10,12,13$

\section{Kesimpulan}

Kadar asam urat, LDH, AST pada pasien preeklamsi berat disertai komplikasi lebih tinggi dibandingkan preeklamsi berat tanpa komplikasi. Didapatkan juga kesimpulan bahwa peningkatan kadar asam urat, LDH, AST berhubungan dengan peningkatan risiko terjadinya komplikasi pada pasien preeklamsi berat. Kadar asam urat, $\mathrm{LDH}$, dan AST merupakan prediktor risiko terjadinya komplikasi yang terpercaya pada kasus preeklamsia berat.

\section{Daftar Pustaka}

1. Hidayat D. Epidemiologi. In: Sabarudin U, Pribadi A, Pramatirta AY, editors. Preeklamsi. 1 ed. Bandung: Dep./ SMF Obstetri \& Ginekologi Fakultas Kedokteran Universitas Padjadjaran RSUP DR. Hasan Sadikin 2015. p. 3-9.

2. Cunningham FG, Leveno KJ, Bloom SL, 
Spong CY, Dashe JS, Hoffman BL, et al. Williams Obstetrics. 24 ed. New York: The McGraw-Hill Companies; 2014.

3. Laporan Tahunan 2015. Bandung: SMF Departemen Obstetri dan Ginekologi/FK Unpad RSUP DR. Hasan Sadikin; 2015. p. 41-2.

4. Krisnadi S. Penatalaksanaan Komplikasi Preeklamsi. In: Sabarudin U, Pribadi A, Pramatirta AY, editors. Preeklamsi. Bandung: Dep./SMF Obstetri \& Ginekologi Fakultas Kedokteran Universitas Padjadjaran RSUP DR. Hasan Sadikin 2015. p. 49-59.

5. Martin JN, Jr., May WL, Magann EF, Terrone DA, Rinehart BK, Blake PG. Early risk assessment of severe preeclampsia: admission battery of symptoms and laboratory tests to predict likelihood of subsequent significant maternal morbidity. Am J Obstet Gynecol. 1999;180(6 Pt 1):1407-14.

6. Bainbridge SA, Roberts JM. Uric acid as a pathogenic factor in preeclampsia. Placenta. 2008;29:67-72.

7. Johnson RJ, Kang D-H, Feig D, Kivlighn $\mathrm{S}$, Kanellis J, Watanabe S, et al. Is there a pathogenetic role for uric acid in hypertension and cardiovascular and renal disease? Hypertension. 2003;41(6):118390.

8. Parrish M, Griffin M, Morris R, Darby M, Owens MY, Martin Jr JN. Hyperuricemia facilitates the prediction of maternal and perinatal adverse outcome in patients with severe/superimposed preeclampsia. The Journal of Maternal-Fetal \& Neonatal Medicine. 2010;23(12):1451-5.
9. Andrews L, Patel N. Correlation of serum lactate dehydrogenase and pregnancy induced hypertension with its adverse outcomes. International Journal of Research in Medical Sciences. 2016;4(5):1347-50.

10. Panteghini M, Solinge WWv. Enzymes. In: Burtis CA, Ashwood ER, bruns DE, editors. Tietz Textbook of Clinical Chemistry and Molecular Diagnostics. 1. 4 ed. Missouri: Elsevier Saunders; 2006. p. 597-643.

11. Umasatyasri Y, Van I, Shamita P. Role of LDH (Lactate dehydrogenase) in preeclampsia eclampsia as a prognostic marker: An observational study. 2015.

12. Thangaratinam S, Koopmans CM, Iyengar S, Zamora J, Ismail KM, Mol $\mathrm{BW}$, et al. Accuracy of liver function tests for predicting adverse maternal and fetal outcomes in women with preeclampsia: a systematic review. Acta obstetricia et gynecologica Scandinavica. 2011;90(6):574-85.

13. Demir C, Evruke C, Ozgunen FT, Urunsak IF, Candan E, Kadayifci O. Factors that influence morbidity and mortality in severe preeclampsia, eclampsia and hemolysis, elevated liver enzymes, and low platelet count syndrome. Saudi medical journal. 2006;27(7):1015-8. 